CZASOPISMO INŻYNIERII LA¿DOWEJ, ŚRODOWISKA I ARCHITEKTURY JOURNAL OF CIVIL ENGINEERING, ENVIRONMENT AND ARCHITECTURE

JCEEA, t. XXXIII, z. 63 (2/I/16), kwiecień-czerwiec 2016, s. 475-486

\author{
Izabela SKRZYPCZAK ${ }^{1}$ \\ Janusz KOGUT $^{2}$ \\ Lidia BUDA- OŻóG ${ }^{3}$ \\ Joanna KUJDA ${ }^{4}$
}

\title{
PROJEKTOWANY OKRES UŻYTKOWANIA A DOCELOWY POZIOM NIEZAWODNOŚCI WEDŁUG RÓŻNYCH ZALECEŃ
}

\begin{abstract}
Docelowe wartości poziomów (wskaźników) niezawodności według różnych zaleceń normowych krajowych i międzynarodowych nie są spójne. Zalecane wartości wskaźników niezawodności są zwykle podawane dla jednego lub dwóch okresów odniesienia (1 rok i 50 lat), bez wyraźnego odniesienia do projektowanego okresu użytkowania. W artykule podjęto próbę wyjaśnienia związku między wymaganym wskaźnikiem niezawodności i projektowanym okresem użytkowania oraz określenia zależności pomiędzy docelowym poziomem niezawodności dla zadanych konsekwencji zniszczenia a projektowanym okresem użytkowania i stopą dyskontową. Analizowano zalecenia zawarte w PN-EN 1990, PN-ISO 2394 i JCSS: 2001. Probabilistic Model Code. Ze wspomnianych tutaj norm/dokumentów nie wynika wyraźny związek między projektowanym okresem użytkowania i docelowym poziomem niezawodności. Analizując niezawodność w odniesieniu do projektowanego okresu użytkowania można stwierdzić, że zwiększenie jakości i niezawodności powoduje wzrost kosztów realizacji/wybudowania obiektu budowlanego, sprawia jednak, że maleją koszty użytkowania, eksploatacji i straty wynikające np. z pojawiających się uszkodzeń obiektu podczas użytkowania. Dokonując weryfikacji docelowych wskaźników niezawodności według różnych zaleceń normowych, krajowych i zagranicznych, można stwierdzić, że optymalne wskaźniki niezawodności zależą przede wszystkim od stosunku kosztów awarii konstrukcji (koszty nieprawidłowo użytkowanej konstrukcji), natomiast mniej istotny wpływ na projektowany okres użytkowania i docelowy wskaźnik niezawodności według M. Holicky’ego ma wartość stopy dyskonta nieruchomości.
\end{abstract}

Słowa kluczowe: wskaźnik niezawodności, konsekwencje zniszczenia, koszty

\footnotetext{
${ }^{1}$ Autor do korespondencji / corresponding author: Izabela Skrzypczak, Politechnika Rzeszowska, Zakład Geodezji i Geotechniki im. Kaspra Weigla, ul. Poznańska 2, 35-959 Rzeszów; tel. 178651010; izas@prz.edu.pl

2 Janusz Kogut, Politechnika Krakowska; jkogut@pk.edu.pl

${ }^{3}$ Lidia Buda-Ożóg, Politechnika Rzeszowska; lida@ prz.edu.pl

3 Joanna Kujda, Politechnika Rzeszowska, joannakujda@wp.pl
} 


\section{Wprowadzenie}

Termin niezawodność, we współczesnych normach do projektowania konstrukcji budowlanych oznacza zdolność konstrukcji do spełnienia określonych wymagań i obejmuje nośność, użytkowalność i trwałość konstrukcji $[1,2]$. Głównym celami inżynierii niezawodności są: zapobieganie lub zmniejszenie prawdopodobieństwa bądź częstości uszkodzeń (zniszczenia) projektowanych obiektów, identyfikacja przyczyn uszkodzeń, ustalenie sposobów postępowania w wypadku wystąpienia uszkodzeń oraz opracowanie metod szacowania niezawodności projektowanych obiektów i analizy odpowiednich danych statystycznych [6]. Jednak docelowe poziomy niezawodności zalecane w różnych dokumentach krajowych i międzynarodowych [1-3] są niespójne zarówno pod względem zalecanych wartości jak i kryteriów, zgodnie z którymi właściwe wartości mają być przyjmowane.

\section{Zalecenia PN-EN 1990}

W Eurokodzie 1990 [1] wyodrębniono wymagania podstawowe oraz dotyczące: niezawodności (zarządzanie niezawodnością), projektowego okresu użytkowania, trwałości i jakości (zarządzanie jakością). Wymagania podstawowe mówią, że konstrukcję należy zaprojektować i wykonać w taki sposób, aby w zamierzonym okresie użytkowania, z należytym poziomem niezawodności i bez nadmiernych kosztów przejmowała wszystkie oddziaływania i wpływy, których pojawienia się można oczekiwać podczas wykonania i użytkowania, oraz pozostała przydatna do przewidzianego użytkowania.

Projektowy okres użytkowania to przyjęty w projekcie przedział czasu T, w którym konstrukcja lub jej część ma być użytkowana zgodnie z zamierzonym przeznaczeniem i przewidywanym utrzymaniem, bez potrzeby większych napraw. Zalecane wg Eurokodu 1990 [1], orientacyjne wartości T można przyjmować następująco:

- konstrukcje tymczasowe 10 lat,

- wymienne części konstrukcji (np. łożyska, belki podsuwnicowe) 10 - 25 lat,

- konstrukcje rolnicze i podobne 15 - 30 lat,

- konstrukcje budynków i inne „zwykłe” konstrukcje - 50 lat,

- konstrukcje budynków monumentalnych, mosty, wiadukty, itp. - 100 lat.

Z kolei zalecane w załączniku B PN-EN 1990 wartości wskaźników niezawodności podane są dla dwóch okresów referencyjnych 1 rok i 50 lat (patrz tab. 1), bez wyraźnego związku z projektowanym okresem użytkowania, które na ogół różni się od okresu odniesienia. Praktyczne zastosowanie tych wartości, związane jest z rozpatrywanym okresem odniesienia, który może być związany $\mathrm{z}$ dostępnością informacji dotyczącą probabilistycznej zmienności podstawowych zmiennych (jednoczesność występowania obciążeń, wiatr, osuwiska, itp.). 
Tabela 1. Klasyfikacja niezawodności na podstawie PN-EN 1990 [1]

Table 1. Classification the reliability based on PN-EN 1990 [1]

\begin{tabular}{|c|c|c|c|c|}
\hline \multirow{2}{*}{$\begin{array}{c}\text { Klasa niezawod- } \\
\text { ności konstrukcji }\end{array}$} & $\begin{array}{c}\text { Konsekwencje } \\
\text { awarii konstrukcji }\end{array}$ & \multicolumn{2}{|c|}{$\begin{array}{c}\text { Wskaźnik nieza- } \\
\text { wodności dla okresu } \\
\text { odniesienia }\end{array}$} & $\begin{array}{c}\text { Przykłady budynków } \\
\text { i obiektów } \\
\text { inżynierii lądowej } \\
\text { i wodnej }\end{array}$ \\
\cline { 3 - 4 } RC3 - Wysoka & Duże & 5,2 & 4,3 & $\begin{array}{c}\text { Mosty, obiekty użytecz- } \\
\text { ności publicznej }\end{array}$ \\
\hline RC2 - Średnia & Średnie & 4,7 & 3,8 & $\begin{array}{c}\text { Budynki i konstrukcje } \\
\text { zwykłe }\end{array}$ \\
\hline RC1 - Niska & Małe & 4,2 & 3,3 & Budowle rolnicze \\
\hline
\end{tabular}

Pojęcie okresu odniesienia jest zatem podstawą do przyjęcia (określenia) projektowanego okresu użytkowania. Dlatego bardzo ważne jest rozróżnienie tych dwóch pojęć, gdy różnica między tymi dwoma pojęciami nie jest zauważalna, mogą pojawić się nieścisłości z określeniem niezawodności konstrukcji. Przypomnijmy, że okres odniesienia to przedział czasowy przyjęty jako podstawa do statystycznego określenia oddziaływań zmiennych i jeśli to możliwe wyjątkowych na konstrukcję.

Należy zauważyć, że wartości $\beta$, dla okresu odniesienia 1 roku oraz 50 lat, podanych w tabeli 1, dla każdej klasy niezawodności, odpowiadają tym samym klasom niezawodności konstrukcji. Praktyczne zastosowanie tych wartości, powinno być uzależnione od rozpatrywanego okresu odniesienia, który może być związany z dostępnymi informacjami dotyczącymi zmiennych podstawowych o charakterze losowym dla okresu użytkowania (jednoczesność wystąpienia obciążenia, wiatr, trzęsienia ziemi, ruchy masowe, itp.). Na przykład, biorąc pod uwagę klasę RC2 niezawodności konstrukcji oraz okres odniesienia 50 lat, wskaźnik niezawodności $\beta=3,8$ powinien być stosowany pod warunkiem, że probabilistyczne modele zmiennych podstawowych są dostępne dla tego okresu. Ten sam poziom niezawodności jest osiągany, gdy okres odniesienia zostanie przyjęty jako okres 1 roku, a wartość wskaźnika niezawodności $\beta=4,7$ została obliczona przy użyciu tych samych modeli teoretycznych jak dla okresu 50 lat.

Zgodnie z Eurokodem 1990 optymalny poziom niezawodności uzyskano biorąc pod uwagę zarówno koszty budowy oraz przewidywane koszty awarii przez cały projektowany okres użytkowania (por. Tab. 1).

\section{Zalecenia PN-ISO 2394}

Bardziej szczegółowe zalecenia dotyczące docelowej niezawodności podane są w normie PN-ISO 2394 [2], gdzie docelowe wartości wskaźnika niezawodności zostały podane dla całego okresu pracy konstrukcji (bez ograniczeń), więc nie są tylko związane $\mathrm{z}$ konsekwencjami awarii, ale zależą również od względnych kosztów środków zapewnienia bezpieczeństwa (patrz Tab. 2). 
Tabela 2. Przykłady docelowych wartości wskaźników niezawodności na podstawie normy PNISO 2394 [2]

Table 2. Examples of target values of reliability based on PN-ISO 2394 [2]

\begin{tabular}{|c|c|c|c|c|}
\hline \multirow{2}{*}{$\begin{array}{c}\text { Względne koszty } \\
\text { zapewnienia } \\
\text { bezpieczeństwa }\end{array}$} & małe & odczuwalne & umiarkowane & wielkie \\
\cline { 2 - 5 } & 0,0 & 1,5 & 2,3 & 3,1 \\
\hline Wysokie & 1,3 & 2,3 & 3,1 & 3,8 \\
\hline Umiarkowane & 2,3 & 3,1 & 3,8 & 4,3 \\
\hline Niskie & & & & \\
\hline
\end{tabular}

Z ekonomicznego punktu widzenia, docelowy poziom niezawodności powinien zależeć od równowagi między skutkami niespełnienia wymagań (np. awarią, zniszczeniem) a kosztem środków zabezpieczających. Formalnie, celem może by minimalizacja całkowitego kosztu w stosunku do czasu/okresu użytkowania, sformułowanego w postaci funkcjonału:

$$
C_{\text {tot }}=C_{b}+C_{m}+\sum P_{f} C_{f}
$$

gdzie: $C_{b}-$ koszt wzniesienia budowli

$C_{m}$ - przewidywany koszt rozbiórki

$C_{f}-$ koszt zniszczenia

$P_{f}$ - prawdopodobieństwo zniszczenia w trakcie użytkowania.

Warto podkreślić, że koszty związane z wartością członu $\sum P_{f} C_{f}$ mogą zostać pokryte przez firmy reasekuracyjne.

W zalecanej w PN-ISO 2394 [2], formule (1), sumowanie jest wykonywane dla wszystkich niezależnych rodzajów zniszczenia i kombinacji obciążenia. Zalecany funkcjonał jest bardzo uproszczony i może wymagać dalszego rozbudowania, zanim będzie zastosowany w praktyce. Do rozważań ekonomicznych, wymagane może być określenie np. minimalnego poziomu niezawodności, jeżeli bezpieczeństwo ludzi jest zagrożone. Może to prowadzić do zagadnienia optymalizacji z ograniczeniami, przy przyjęciu równania (1), jako funkcji celu oraz równań (2) lub (3) jako ograniczeń:

$$
\begin{aligned}
& P(f / \text { year }) P(d / f)<10^{-6} \text { year }^{-1} \\
& P(f / \text { year })<A N^{\alpha}
\end{aligned}
$$

gdzie: $N$ - przewidywana liczba zgonów,

$A$ i $\alpha$ - są stałymi.

$A=0,01$ albo 0,1 i $\alpha=2$. Modyfikacja stałych liczbowych jest możliwa w szczególnych przypadkach np. jeżeli istnieje plan ewakuacji w sytuacji zagrożenia (rys. 1). 


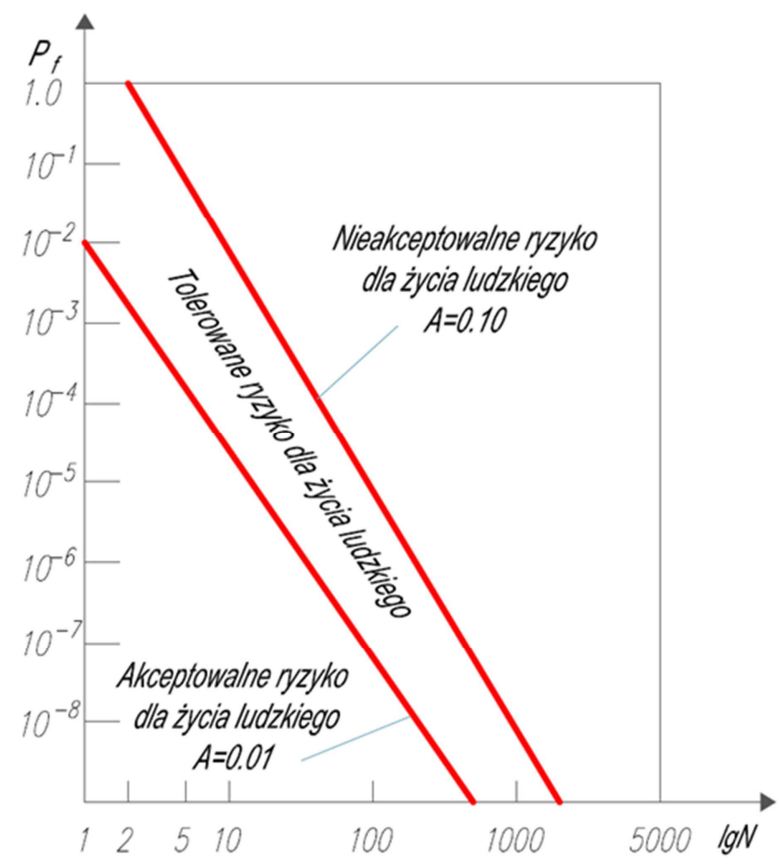

Rys. 1. Diagram ilościowego poziomu akceptowalności ryzyka wg [2]

Fig. 1. Diagram quantify the level of acceptability of risk based on [2]

W normie PN-ISO 2394 [2] podano uproszczoną formułę na określenie całkowitego kosztu zapewnienia niezawodności konstrukcji. Alternatywna postać wzoru, dla probabilistycznej optymalizacji określenia docelowego poziomu niezawodności przy tak określonej funkcji celu, może być zdefiniowana jako wartość całkowitego kosztu zgodnie z formułą:

$$
C_{\text {tot }}(x, q, n)=C_{f} \sum_{i=1}^{n} P_{f}(x, i) Q(q, i)+C_{0}+x C_{i}
$$

gdzie: $x$ - parametr decyzji optymalizacji,

$q$ - roczna stopa dyskontowa,

$n$ - liczba lat,

$P_{f}(x, i)$ - prawdopodobieństwa awarii w $i$-tym roku,

$Q(q, i)$ - parametr dyskontowy (wartość bieżąca przyszłych kosztów),

$C_{o}$ - koszt początkowy,

$C_{i}$ - koszt jednostkowy parametru decyzyjnego,

$C_{f}$ - niewłaściwe oszacowane koszty na poszczególnych etapach realizacji i eksploatacji.

Postać tego wzoru została zaproponowana przez M. Holicky'ego i M. Sykorę oraz J. Retiefa m.in. w [4, 5]. 
W analizie niezawodności konstrukcji, zmienne we wzorze (4) można zdefiniować jako: $x$ - parametr decyzji optymalizacji (parametr odporności konstrukcji), $q$ - roczna stopa dyskontowa (np. $q=0,03$, średnią wartość długości prowadzonej rzeczywistej rocznej stopy dyskontowej w krajach europejskich), $n$ liczba lat projektowanego okresu użytkowania (np. 30, 100), $P_{f}(x, i)$ - prawdopodobieństwo awarii w $i$-tym roku, $C_{f}$ - koszty nieprawidłowego użytkowania konstrukcji (z powodu przekroczenia np. stanów granicznych użytkowności konstrukcji), $Q(q, i)$ współczynnik dyskontowy w zależności od rocznej $q$ stopy dyskontowej oraz liczba lat $n, C_{0}$ - początkowy koszt niezależnych decyzji $x$, oraz $C_{\mathrm{i}}$ - koszty na jednostkę parametru $x$ decyzji.

Należy zauważyć, że koszt konstrukcji zgodnie ze wzorem (4) jest stały i zdeterminowany przez wiele lat. W rzeczywistości żywotność konstrukcji dla danego projektowanego okresu użytkowania może być losowa i zależna zarówno od czynników społecznych i jak i fizycznych. Sam projekt realizacji konstrukcji budowlanej może zmierzać do pewnego optimum.

Przyjęcie odpowiedniego poziomu niezawodności konstrukcji jest ważne przede wszystkim wówczas, gdy w razie jej zniszczenia mogą zginąć lub ulec obrażeniom ludzie, wówczas dopuszczalna maksymalna wartość prawdopodobieństwa zniszczenia konstrukcji zależy od warunkowego prawdopodobieństwa śmierci osoby w danej katastrofie konstrukcji zgodnie ze wzorem (2). Wymaganie to dotyczy jednego roku, przy czym bezpieczeństwo ludzi i prawdopodobieństwo śmierci ludzi w budynku podczas katastrofy, należy rozpatrywać jako średnia wartość w okresie odniesienia. Na ogół dopuszczalne jest przyjęcie większego prawdopodobieństwa katastrofy w pewnej części okresu odniesienia, a mniejszej w innej części. Okres odniesienia nie musi być równy okresowi użytkowania konstrukcji. Należy podkreślić, że równanie (2) daje minimalne wymaganie dotyczące bezpieczeństwa ludzi. W wielu przypadkach, w celu uniknięcia sytuacji, w których może zginąć większa liczba osób, należy stosować dodatkowe wymaganie w postaci (3).

\section{Zalecenia JCSS: 2001. Probabilistic Model Code}

Podobne zalecenia dotyczące poziomów niezawodności zawarte są w normie JCSS: 2001. Probabilistic Model Code [3] (Tabela 3).

Zalecane docelowe wskaźniki niezawodności są związane zarówno z konsekwencjami jak i względnymi kosztami zapewnienia bezpieczeństwa. Są one jednak zdefiniowane dla okresu odniesienia wynoszącemu 1 rok. Klasy konsekwencji w [3] (są podobne do tych, które są zawarte w PN-EN 1990 [1]) i są one połączone współczynnikiem $\rho$ i zdefiniowanym jako stosunek całkowitych kosztów (koszt realizacji obiektu powiększony o bezpośrednie koszty awarii) i kosztów budowy w następujący sposób:

- Klasa 1 - Małe Konsekwencje: wartość $\rho<2$, zagrożenie dla życia jest małe lub jest jego brak, występują znikome lub nieistotne konsekwencje ekono 
Tabela 3. Docelowe wskaźniki niezawodność $\beta$ (i związane z nimi docelowe konsekwencje zniszczenia) dla okresu odniesienia jednego roku i stanów granicznych podanych w JCSS [3]

Table 3. Targets reliability $\beta$ (and related targets consequences of failure) for the reference period of one year and the limit states based on JCSS [3]

\begin{tabular}{|c|c|c|c|}
\hline $\begin{array}{c}\text { Względne koszty } \\
\text { zapewnienia bez- } \\
\text { pieczeństwa }\end{array}$ & $\begin{array}{c}\text { Małe konsekwencje } \\
\text { zniszczenia }\end{array}$ & $\begin{array}{c}\text { Średnie konsekwencje } \\
\text { zniszczenia }\end{array}$ & $\begin{array}{c}\text { Duże konsekwencje } \\
\text { zniszczenia }\end{array}$ \\
\hline Duże & 3,1 & 3,3 & 3,7 \\
\hline Normalne & 3,7 & 4,2 & 4,4 \\
\hline Małe & 4,2 & 4,4 & 4,7 \\
\hline
\end{tabular}

miczne (np. konstrukcje rolnicze, silosy, maszty);

- Klasa 2 - Umiarkowane Konsekwencje: $2<\rho<5$, brak jest lub występuje średnie zagrożenie dla życia ludzi lub skutki ekonomiczne są znaczne (np. budynki biurowe, budynki przemysłowe, budynki mieszkalne);

- Klasa 3 - Duże Konsekwencje: $5<\rho<10$, zagrożenie dla życia, ze względu na awarię, jest wysokie, lub skutki ekonomiczne są znaczące (np. mosty, teatry, hale widowiskowe, szpitale, budynki wysokie).

W przypadku, gdy $\rho>10$ oraz konsekwencje należy uznać za ekstremalne zaleca się pełną analizę kosztów i korzyści. W takim przypadku może się okazać, że konstrukcji nie należy budować (realizować).

Normalne klasy konsekwencji zniszczenia powinny być związane:

- ze średnią zmiennością dla całkowitych obciążeń i nośności $(0,1<\mathrm{V}<0,3)$,

- z względnymi średnimi kosztami zapewnienia bezpieczeństwa,

- z kosztami związanymi z projektowanym okresem użytkowania oraz starzenia się konstrukcji (zwykle to koszty ok. 3\% budowy).

W przypadku dużych niepewności albo obciążenia lub nośności (współczynniki zmienności większe niż 0,4 ), jak na przykład realizacja obiektów na terenach zalewowych, osuwiskowych, w opinii autorów, powinny być stosowane klasy niższej niezawodności. Dla dużych niepewności dodatkowe koszty w celu osiągnięcia wysokiej niezawodności mogą być zbyt wygórowane i czasami wręcz ekonomicznie nieuzasadnione.

Zapewnienie jakości (dla nowych konstrukcji) i przeglądy (dla istniejących konstrukcji) wpływają na koszty zapewnienia niezawodności. W większości przypadków działania takie prowadzą do niższej klasy niezawodności. Z drugiej strony, ze względu na kontrole jakości i inspekcje zmniejsza się niepewność i wyższe klasy niezawodności stają się ekonomicznie bardziej uzasadnione. Dla istniejących konstrukcji koszty osiągnięcia wyższego poziomu niezawodności są zazwyczaj wysokie w porównaniu do konstrukcji projektowanych czy nowo realizowanych. Z tego powodu docelowe poziomy dla istniejących obiektów zwykle powinny być niższe.

W przypadku konstrukcji tymczasowych lub elementów wymienialnych, dla których okres użytkowania przyjmuje się na poziomie 10 lat, docelowe war- 
tości wskaźnika niezawodności $\beta$ mogą być obniżone np. o jedną lub pół klasy. Podczas ustalania wartości docelowych wskaźnika niezawodności dla stanów granicznych użytkowalności (SLS) ważne jest, aby rozróżniać nieodwracalne i odwracalne stany graniczne użytkowalności. Wartości docelowe dla SLS mogą być uzyskane na podstawie metody analizy decyzji. Dla nieodwracalnych stanów granicznych użytkowalności wstępne wartości docelowe są podane w tabeli 3.

\section{Koszty a niezawodność obiektów budowlanych}

Na poziom niezawodności oraz dobrą jakość obiektów budowlanych projektowanych na okres użytkowania ma wpływ nie tylko koszt początkowy (koszt wybudowania/realizacji), lecz także oczekiwany koszt jego eksploatacji i utrzymania. Zapewnienie odpowiedniej niezawodności funkcjonowania obiektu jest naczelnym zadaniem jego użytkownika, ale to już projektanci i wykonawcy powinni dążyć do wytworzenia obiektów o optymalnej niezawodności oraz dzięki optymalizacji kosztów, konkurencyjnych pod względem kosztu realizacji. Proces optymalizacji powinien rozpocząć się wraz z początkiem prac nad obiektem i rozciągać się tak, aby uwzględnić wszystkie koszty, które pojawią się w czasie istnienia obiektu. Wszystkie podjęte decyzje dotyczące projektu i realizacji obiektu mają wpływ na jego bezpieczeństwo, niezawodność, użytkowalności, a wymagania użytkowników dotyczące eksploatacji ostatecznie określają jego cenę oraz późniejsze koszty utrzymania $[8,10]$.

Problem analizy kosztów w realizacji obiektów budowlanych był zawsze uwzględniany, ale rzadko analizowany w aspekcie projektowanego okresu użytkowania. Literatura z zakresu analizy kosztów jakości i niezawodności jest liczna. Artykuły, monografie, normy przedstawiają różne aspekty tej analizy [7-11].

Istotnym czynnikiem determinującym koszty obiektu budowlanego projektowanego na okres użytkowania jest jego niezawodność. Z jednej strony niska niezawodność obiektu jest przyczyną strat ekonomicznych, z drugiej strony, zwiększenie niezawodności powoduje zwiększenie kosztów wykonania obiektu, mających m.in. wpływ na koszty użytkowania obiektu. Zależność kosztów od poziomu niezawodności można przedstawić zgodnie z poniższym schematem (rys. 2).

Analizując rys. 2, można zauważyć, że jeśli wydatki na realizację obiektu rosną, to wszystkie parametry związane z zapewnieniem niezawodności też mają tendencje wzrostowe, a to z kolei obniża koszty eksploatacji (użytkowania, utrzymania). Przyjmuje się, że koszt eksploatacji obiektu jest odwrotnie proporcjonalny do jego niezawodności. Krzywa kosztu całkowitego istnienia obiektu osiąga minimum, które odpowiada optymalnemu ekonomicznie poziomowi niezawodności. W punkcie tym niezawodność spełnia oczekiwania użytkownika przy określonych kosztach poniesionych na użytkowanie i realizację obiektu (wybudowanie). Aby go określić należy ustalić funkcje celu (np. efektywności ekonomicznej), a także postać matematyczną zależności tej funkcji od poziomu 


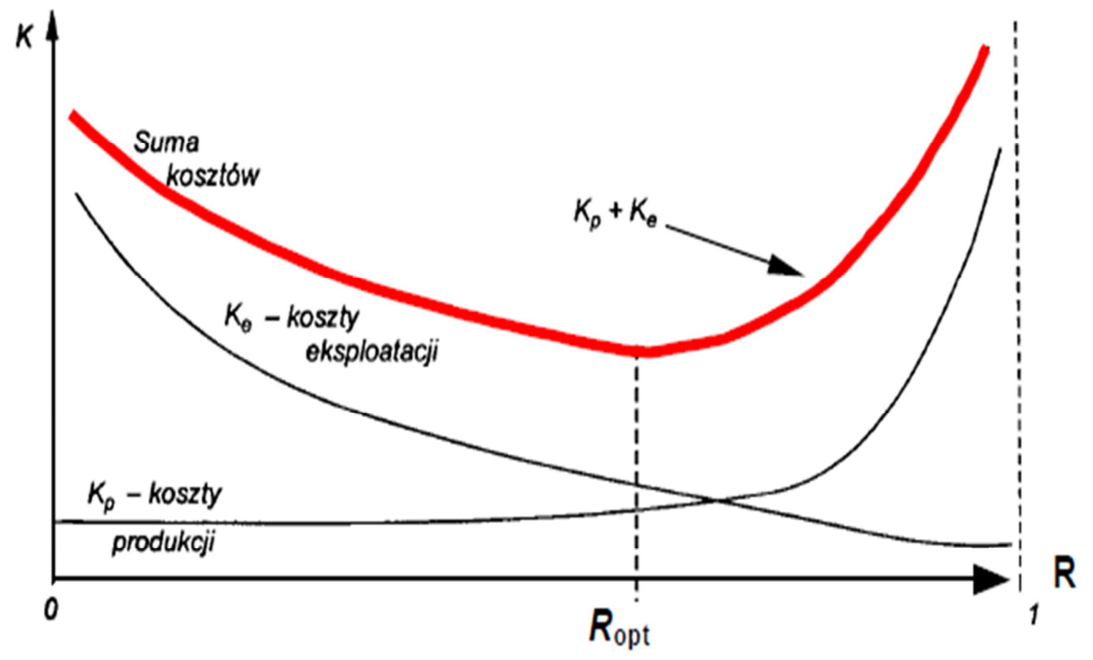

Rys. 2. Zależność niezawodności obiektu budowlanego od kosztów wg [9]

Fig. 2. The dependence the reliability of a building and the cost, based on [9]

niezawodności np. zgodnie ze wzorami (1) do (3) lub zgodnie z formułą zaproponowana przez M. Holicky'ego i współautorów (4).

Niezawodność i wyższa jakość projektowanego obiektu budowlanego wymaga dla jej zrealizowania większych kosztów, lecz podnosi relatywną wartość obiektu (wartość dyskontowa). Można tu mówi o ekonomicznie optymalnej jakości projektowej obiektu budowlanego (rys. 3).

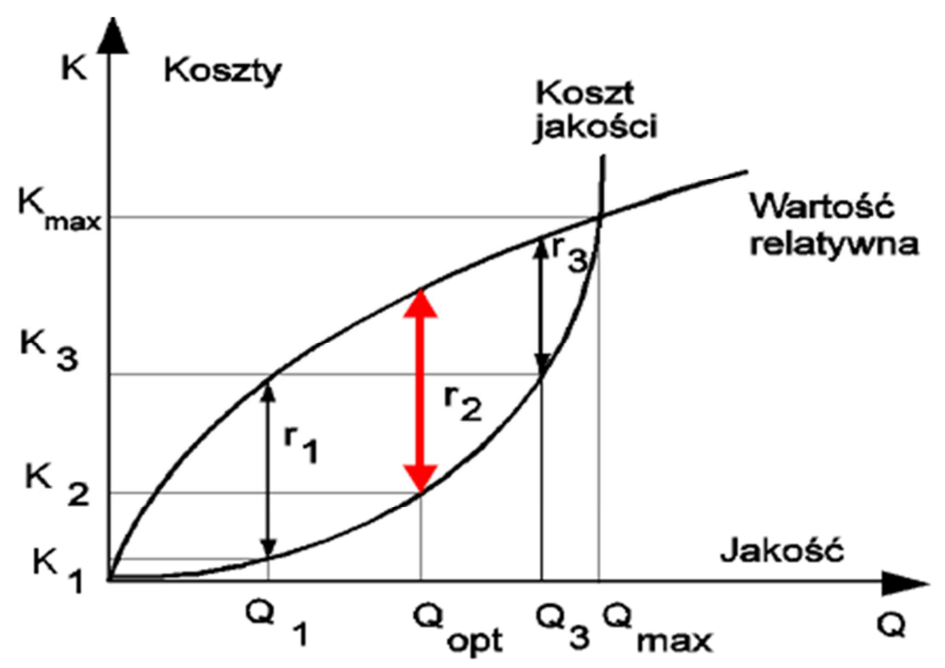

Rys. 3. Zależność kosztów od jakości wg [9]

Fig. 3. The dependence the cost and the quality, based on [9] 
Największa część kosztów pojawia się pod koniec okresu istnienia obiektu tj. w końcowym czasie jego eksploatacji. W tej fazie to użytkownik/właściciel dba o zapewnienie odpowiedniej niezawodności obiektu budowlanego. To od niego zależy wysokość kosztów eksploatacji obiektu, jakie poniesie w całym okresie jego użytkowania, a te niewątpliwie w dużej mierze zależą od poziomu niezawodności obiektu ukształtowanego we wcześniejszych fazach istnienia. To właśnie przyszłe koszty związane z elementami niezawodności obiektu są najtrudniejsze do oszacowania, przede wszystkim ze względu na losowy charakter pojawiania się uszkodzeń.

Zwiększenie jakości i niezawodności powoduje wzrost kosztów realizacji/wybudowania obiektu budowlanego, sprawia jednak, że maleją koszty użytkowania, eksploatacji i straty wynikające np. z pojawiających się uszkodzeń obiektu podczas użytkowania. Jeśli wyznaczy się zależność sumy kosztów wzniesienia obiektu i kosztów użytkowania od jego niezawodności w zakładanym czasie, to może się okazać, że dla pewnej niezawodności wystąpi minimalna wartość tej sumy. Taką niezawodność można, w opinii autorów, uznać za ekonomicznie optymalną niezawodność obiektu budowlanego.

\section{Uwagi końcowe}

Ze wspomnianych tutaj norm/dokumentów nie wynika wyraźny związek między projektowanym okresem użytkowania i docelowym poziomem niezawodności. Tak więc, nie jest jasne, jaka wartość docelowego wskaźnika niezawodności powinna być stosowana dla danego projektowanego okresu użytkowania różniącego się od 50 lat (powiedzmy 10 lat).

Dokumenty PN-ISO 3294 [2] i JCSS: 2001 Probabilistic Model Code [3] zalecają wskaźniki niezawodności niższe niż podane w EN 1990 [1], nawet przy małych kosztach względnych środków bezpieczeństwa. Należy zauważyć, że EN 1990 [1] podaje zalecane wskaźniki niezawodności dla dwóch okresów odniesienia 1 do 50 lat, które mogą zostać uznane za cały projektowany okres użytkowania dla zwykłych konstrukcji (analizy przedstawione w [4]). ISO 2394 [2] zaleca wskaźniki dla okresu użytkowania, co związane z jest projektowanym okresem użytkowania, a JCSS: 2001 Probabilistic Model Code [3] określa wskaźniki niezawodności dla okresu odniesienia wynoszącego 1 rok.

Analizując niezawodność w odniesieniu do projektowanego okresu użytkowania można stwierdzić, że zwiększenie jakości i niezawodności powoduje wzrost kosztów realizacji/wybudowania obiektu budowlanego, sprawia jednak, że maleją koszty użytkowania, eksploatacji i straty wynikające np. z pojawiających się uszkodzeń obiektu podczas użytkowania.

Zatem ekonomiczne zagadnienia zapewnienia jakości i niezawodności obiektów budowlanych powinny być analizowane już podczas projektowania, przy czym należy wypracować metody ekonomicznej weryfikacji decyzji jakościowych. Jakość i niezawodność obiektu istotnie zależy od tego, czy obiekt ten 
został poprawnie zaprojektowany. Chodzi tu zarówno o jakość samego projektu, jak i zgodność projektu z oczekiwaniami użytkowników/właścicieli/inwestorów. Podsumowując projektowanie nowego obiektu obejmuje wiele czynności, poczynając od specyfikacji wymagań, a kończąc na opracowaniu optymalnego pod względem ekonomicznym rozwiązania konstrukcyjnego.

\section{Literatura}

[1] PN-EN 1990: 2004. Podstawy projektowania konstrukcji. PKN, Warszawa, 2004.

[2] PN-ISO 2394: 2000 Ogólne zasady niezawodności konstrukcji budowlanych, PKN.

[3] Joint Committee on Structural Safety. Probabilistic Model Code, publikacja internetowa, 2001, www.jcss.ethz.ch, dostęp 30-06-2016.

[4] Holicky M., Retief J., Theoretical basis of the target reliability, Proceedings of the $9^{\text {th }}$ IPW, Braunschweig 2011, s. 91-101.

[5] Sykora M., Holicky M., Diamantidis D., Target reliability for existing civil engineering systems, , Second International Symposium on Stochastic Models in Reliability Engineering, Life Science and Operations Management, DOI 10.1109SMRLO.2016.28, s. 109-114.

[6] Woliński Sz., Probabilistyczne podstawy współczesnych norm projektowania, Budownictwo i Inżynieria Środowiska, Zeszyty Naukowe PRz, z. 58, nr 3/2011/1, s. $269-288$.

[7] Aggarwal K.K.: Reliability Engineering. Kluwer Academic Publishers, The Netherlands 1993.

[8] Blanchard B.S., Fabrycky W.: Life-Cycle Cost and Economic Analysis. PrenticeHall, Englewood Cliffs, New York 1991.

[9] Dhillon B.S.: Quality Control, Reliability, and Engineering Design. Industrial Engineering, New York 1985.

[10] Dhillon B.S.: Life Cycle Costing. Techniques, Models and Applications. Gordon and Breach Science Publishers, New York 1989.

[11] Hong T., Han S., Lee S.: Simulation-based determination of optimal life-cycle cost for FRPbridge deck panels. Automation and Constructions, no. 16, s. 140-152, 2007.

\section{THE LEVELS OF RELIABILITY AND PROJECTED LIFETIME DUE TO VARIOUS CODE RECOMMENDATIONS}

\section{S u m m a r y}

The target levels (indicators) of reliability given by the various code recommendations in Poland, both national and international are not consistent. Such recommended values of reliability are usually given for different reference periods (1 year and 50 years), without explicit reference to the designed lifespan of the structure. This paper attempts to clarify the relationship between the required reliability index and the planned lifespan and determine the relationship between the target level of reliability for given consequences of the destruction of projected lifespan and the discount rate of the property. Analyzed the recommendations contained in PN-EN 1990, PN-ISO 2394 
and JCSS: 2001. Probabilistic Model Code. These standards /documents do not indicate a clear link between the planned period of use and a target level of reliability.Analyzing the reliability with respect to the proposed period can be said that an increase in the quality and reliability increases the costs of implementation / construction of a building, makes, however, that declining cost of ownership, operation and losses eg. The emerging object damage during use. In such a verification the target indicators of reliability of various code recommendations, one may conclude that the optimal indicators of reliability depend primarily on the cost structure failure (the costs of improper maintenance of structure). On the other hand, less significant impact on the projected lifetime and target reliability index according to M. Holičky has the value of the discount rate of the property.

Keywords: reliability index, the consequences of the destruction, costs

Przestano do redakcji: $30.08 .2016 r$.

Przyjęto do druku: 15.09.2016 r.

DOI: $10.7862 / \mathrm{rb} .2016 .146$ 